\title{
CD10 Expressing Cell Count
}

National Cancer Institute

\section{Source}

National Cancer Institute. CD10 Expressing Cell Count. NCI Thesaurus. Code C111146.

The determination of the amount of CD10 expressing cells per unit present in a sample. 